CORRECTION

\title{
Correction: Pesticide exposure among Bolivian farmers: associations between worker protection and exposure biomarkers
}

Jessika Barrón Cuenca, Noemi Tirado, Max Vikström, Christian H. Lindh, Ulla Stenius, Karin Leander, Marika Berglund and Kristian Dreij

(C) The Author(s), under exclusive licence to Springer Nature America, Inc. 2021

Journal of Exposure Science \& Environmental Epidemiology (2022) 32:782; https://doi.org/10.1038/s41370-021-00402-9

Correction to: Journal of Exposure Science \& Environmental Epidemiology https://doi.org/10.1038/s41370-019-0128-3

The original article has been corrected.

The original version of this article was not published as Open Access article. The article was made open access retrospectively. (c) (i) Open Access This article is licensed under a Creative Commons adaptation, distribution and reproduction in any medium or format, as long as you give appropriate credit to the original author(s) and the source, provide a link to the Creative Commons license, and indicate if changes were made. The images or other third party material in this article are included in the article's Creative Commons license, unless indicated otherwise in a credit line to the material. If material is not included in the article's Creative Commons license and your intended use is not permitted by statutory regulation or exceeds the permitted use, you will need to obtain permission directly from the copyright holder. To view a copy of this license, visit http://creativecommons. org/licenses/by/4.0/.

(c) The Author(s), under exclusive licence to Springer Nature America, Inc. 2021 